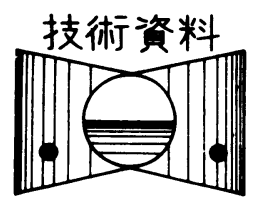

\title{
クロスヘッドピン軸受の負荷能力に 関する各種改善法の比較*
}

\author{
和 栗 雄太郎 $* *$. 浜 武 俊 朗*** \\ 副島光 洋**** - 大坪 勝 ${ }^{* * *}$
}

Comparion of Various Methods for Improving Load-Carrying Capacity of Crosshead-Pin Bearing

By Yutaro Wakuri, Toshiro Hamatake, Mitsuhiro Soejima, Masaru Ohtsubo

A crosshead-pin bearing with axial oil grooves in a two-stroke cycle marine diesel engine is inferior in the load-carrying capacity, since the load acting on the bearing is always unidirectional and the sliding speed is low besides oscillatory motion. Two possible methods for improving the load-carrying capacity have been proposed. One is an offset bearing system that both the journal and the bearing are axially divided into two segments with offset centerlines. The other is a bearing system combined with a circular journal and an elliptical bearing.

The theoretical analyses are conducted for the comparison of load-carrying capacity among three type of the crosshead-pin bearing, a conventional type employed widely, an offest type and an elliptical type. Furthermore, the influences of the bearing oscillation angle on the load-carrying capacity are examined theoretically and experimentally.

\section{1. 緒言}

往復動内然機関に使用されている変動荷重ジャーナル 軸受の多くは，くさび膜作用拉よびスクイーズ膜作用を 伴ら動圧流体潤滑により，此較的厚い油膜のもとで作動 している.しかしながら，低速二サイクルディーゼル機 関のクロスヘッドピン軸受（以下クロス軸受と略称す る）は，軸受各部の寸法が最適な設計条件であっても厚 (油膜を形成できず，油膜の交換能力に劣る ${ }^{1) \sim 4)}$ 。これ は, 軸受の荷重方向が常に一方向で, 低速かつ回転角の 小さな摇動運動しか行わないといらクロス軸受特有の作 動条件に起因している。そのような作動条件のもとで は，厚い油膜を形成する上で不可欠なくさび膜作用によ る油膜圧力がほとんど発生しない，従来のクロス軸受は 図1に示すようにすべり面の油膜交換を促進するために

\footnotetext{
*原稿受付 平成 2 年11月29日

ISME KOBE '90講演（平成 2 年10月 17 日)

**正会員 九州大学（福岡市東区箱崎 6-10-1)

***正会員 大分大学（大分市旦野原 700）

****正会員 九州産業大学 (福岡市東区松香台 2-3-1)

*****九州大学（福岡市東区箱崎 6-10-1)
}

軸方向油溝を設けているが，この油溝の設置により負荷 能力は著しく低下する。したがって，クロス軸受では負 荷能力の改善と油膜交換の促進が重要な課題である。

クロス軸受の負荷能力改善策として，従来形軸受と軸 受形状の異なる二つの動圧軸受が提案されている。一つ は Ciliberto と Mariani ${ }^{5)}$ が考案した偏心形クロス軸受で， 図 2 に示すように軸受は円周方向油溝を境にしてすべり 面が主軸側と偏心軸側に分割され，軸・軸受は偏心構造 となっている。和栗 ${ }^{3(4) 5) ~ 9)}$, Booker ${ }^{1011)}$ はこの形の軸受 について理論解析や実験的研究を行い, 軸と軸受の相対 的な接近運動が主軸側と偏心軸側で交互に起こることか ら，従来形軸受に比べて負荷能力と油膜の交換能力に優 れた軸受であることを明らかにした．

他方は真円軸とだ円軸受で構成された動圧軸受であ る. Goenka と Booker ${ }^{12)}$ は人の股関節の研究に端を発 し，非真円（だ円）形状の軸や軸受を有する部分軸受の 潤滑について理論解析を行った．その結果，軸受の形状 を真円から僅かにだ円に変えると油膜厚さおよび圧力分 布は従来形軸受のそれに比べて著しく改善されることを 示した。これは，負荷膜内に二つの油膜縮流部が存在 し，くさび膜作用による油膜圧力が容易に発生できるこ とに起因している. $\operatorname{Martin}^{13)}$ は，彼らの計算データがク ロス軸受のそれに似ていることから，だ円形軸受のクロ 


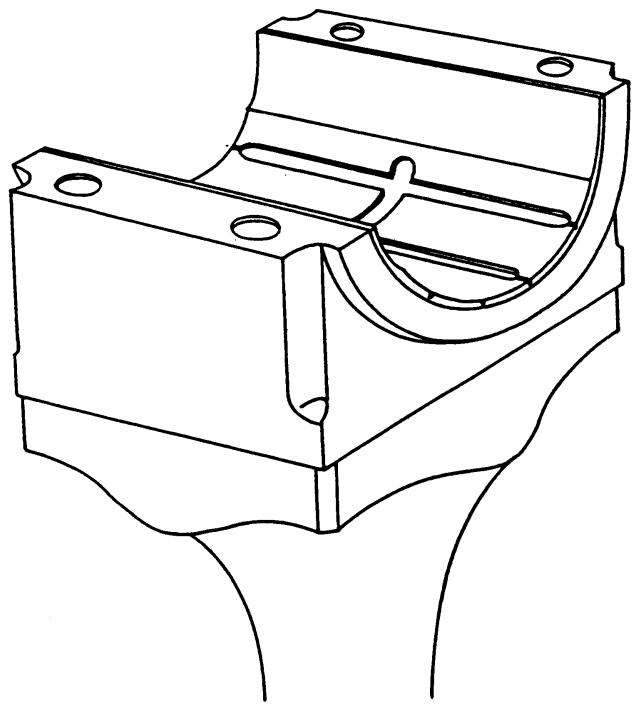

図 1 軸方向油溝を有する従来形クロス軸受

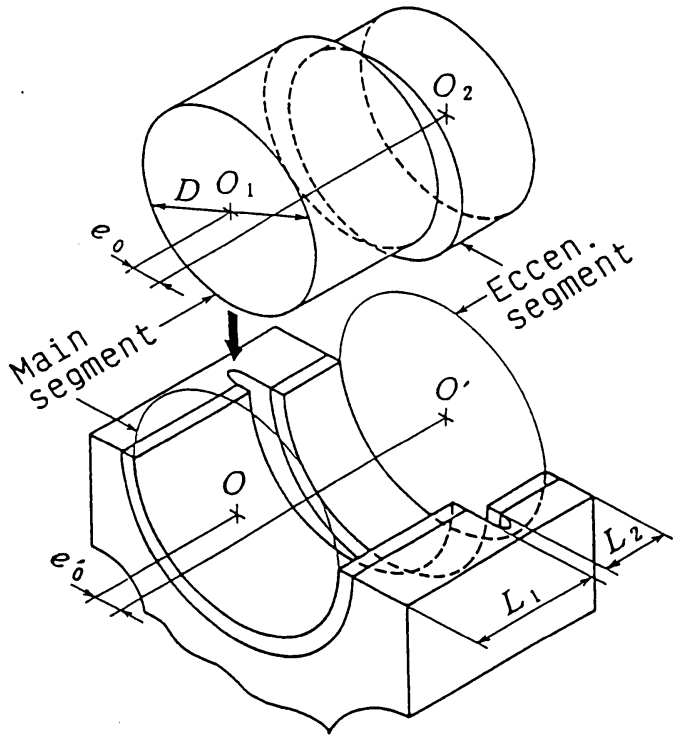

図 2 偏心形軸受

ス軸受への適用を推奖した，著者らは，軸方向油溝を有 するだ円形クロス軸受の潤滑機構を解明し，負荷能力に 及ぼす種々の影響因子を調べた ${ }^{1415)}$.

本研究では以上述べた三形式のクロス軸受の負荷能力 について比較した。また，大形ディーゼル機関の最近の 傾向として，ストロークボア比が約 3 程度の長行程機関 が採用されている．そのため連捍比が小さくなり軸受摇 動角は大きくなりつつあるので, 軸受摇動角の増大が負 荷能力に及ぼす影響についても実験的に調べた。

\section{2. 基 礪 式}

2.1 だ円形軸受図 3 に真円軸とだ円軸受を有 するクロス軸受の解析モデルを示す．クロス軸受は荷重 の方向が連接棒の軸線と一致するので，軸受と荷重方向 を固定しクロスヘッドピンを回転させると考えれば，油 膜圧力を支配するレイノルズ方程式は次のようになる。

$$
\begin{aligned}
& \frac{1}{r^{2}} \frac{\partial}{\partial \theta}\left(\frac{h^{3} \partial p}{\eta \partial \theta}\right)+\frac{\partial}{\partial z}\left(\frac{h^{3} \partial p}{\eta \partial z}\right) \\
& \quad=6 \omega \frac{\partial h}{\partial \theta}+12 e \frac{d \phi}{d t} \sin \theta+12 \frac{d e}{d t} \cos \theta
\end{aligned}
$$

潤滑油の高圧粘度変化を考虑すると，粘度は式(2)で与 えられる。

$$
\eta=\eta_{0} \exp \left(\alpha_{0} p\right)
$$

粘度は圧力の関数であるので, 式(3)で定義する換算圧力 $q$ を用いる

$$
q=\left\{1-\exp \left(-\alpha_{0} p\right)\right\} / \alpha_{0}
$$

式(1)を無次元化して整理すると次のようになる。

$$
\begin{gathered}
\frac{\partial^{2} P}{\partial \theta^{2}}+\left(\frac{r}{L}\right)^{2} \frac{\partial^{2} P}{\partial Z^{2}}-\frac{3}{2 H^{3 / 2}}\left\{\frac{\partial}{\partial \theta}\left(H^{1 / 2} \frac{\partial H}{\partial \theta}\right)\right. \\
\left.+\left(\frac{r}{L}\right)^{2} \frac{\partial}{\partial Z}\left(H^{1 / 2} \frac{\partial H}{\partial Z}\right)\right\} P=\frac{6 \bar{\omega}}{H^{3 / 2}} \frac{\partial H}{\partial \theta} \\
+\frac{12}{H^{3 / 2}}\left(\varepsilon \frac{d \phi}{d \tau} \sin \theta+\frac{d \varepsilon}{d \tau} \cos \theta\right)
\end{gathered}
$$
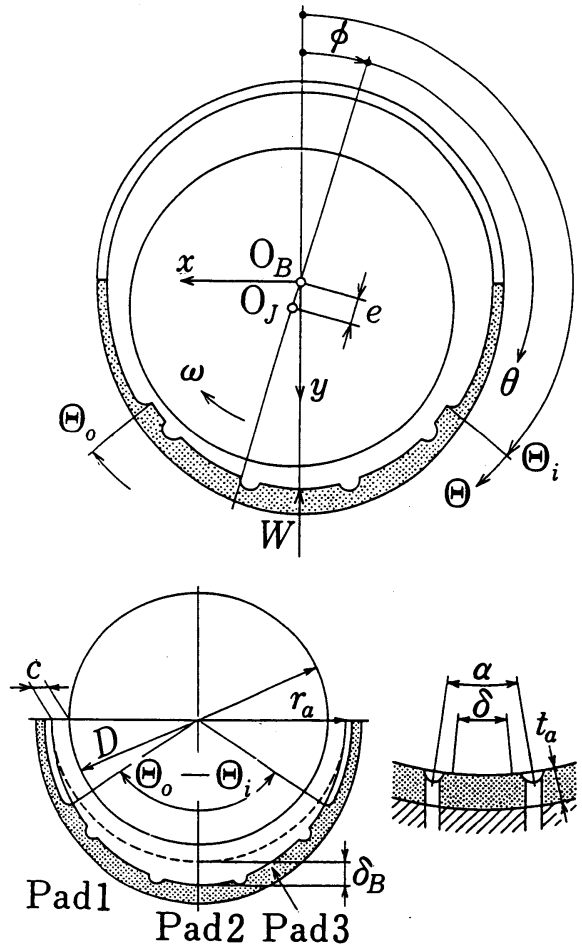

図 3 従来形および円形軸受の解析モデルと座標系 
上式で用いた無次元数は次のようなるのである.

$$
\left.\begin{array}{c}
P=\Psi H^{3 / 2}, \Psi=(c / r)^{2} q / \eta_{0} \omega_{0} \\
H=h / c, Z=z / L, \varepsilon=e / c \\
\tau=\omega_{0} t, \bar{\omega}=\omega / \omega_{0}
\end{array}\right\}
$$

式(4)を差分化し $P$ の離散解を得て逆変換すれば油膜圧力 分布を求めることができる。 その際必要な境界条件を次 のように定める.

$$
\begin{aligned}
& P\left(\theta_{i 1}, Z\right)=P\left(\theta_{i 2}, Z\right)=0 \\
& P(\theta, 0.5)=P(\theta,-0.5)=0
\end{aligned}
$$

だ円形状の円弧半径は，図３に示す記号を用いると，近 似的に式(7)の上らに表される。

$$
r_{B}=r_{a}+\delta_{B} \cos ^{2} \theta
$$

したがって, 軸受メタルの弾性変形を考慮した無次元油 膜厚さは，

$$
H=1+\varepsilon \cos \theta+E_{B} \cos ^{2} \theta+k p / c
$$

ここで,

$$
\left.\begin{array}{l}
c=r_{a}-r \\
E_{B}=\delta_{B} / c \\
k=t_{a}\left\{1-2 \nu^{2} /(1-\nu)\right\} / E
\end{array}\right\}
$$

式(9)の $E_{B}$ を軸受のだ円率と定義する．従来形軸受のよ らに軸受面の形状が真円の場合，軸受のだ円率は零であ る.

油膜圧力による油膜力と軸受荷重の釣合い式は，

$$
\begin{aligned}
& \sum_{i=1}^{m} \int_{-0.5}^{0.5} \int_{\theta_{i 1}}^{\theta_{i 2}} p \cos \theta d \theta d Z+2 p_{\omega} \cos \phi=0 \\
& \sum_{i=1}^{m} \int_{-0.5}^{0.5} \int_{\theta_{i 1}}^{\theta_{i 2}} p \sin \theta d \theta d Z-2 p_{\omega} \sin \phi=0
\end{aligned}
$$

以上の関係式から油膜圧力分布と軸心軌跡を求める が，数值解法の手順を要約すると次のようになる.

(1) 任意のクランク角での軸心の位置およびその速度を 初期値として与之, 油膜圧力分布と軸受メタルの弾性変 形量を計算する。

(2) 式(10)，(11)を満足する軸心速度をニュートンラプソン 法で逐次近似する。

(3) 得られた軸心速度より次のクランク角の軸心位置を オイラー法で求め, 軸心軌跡がサイクル的に安定するま で以上の計算を繰り返す.

2.2 偏心形軸受偏心形軸受の解析モデルを図 4 に示す. 図中の実線は主軸側，破線は偏心軸側を示 し，各軸に関する記号はそれぞれ添字 1 ，添字 2 を付し て表す．前節で示したレイノルズ方程式と油膜厚さの式 が偏心形軸受に执いても適用できる，ただし，式(10)，(11) に相当する油膜力と軸受荷重の釣合い式は，

$$
\begin{aligned}
& \int_{0}^{L_{1} / L} \int_{\theta_{i}}^{\theta_{0}} p_{1} \cos \theta d \theta d Z+ \\
& \quad+\int_{0}^{L_{2} / L} \int_{\theta_{i}}^{\theta_{0}} p_{2} \cos \left(\theta-\phi_{1}+\phi_{2}\right) d \theta d Z \\
& \quad+2 p_{\omega} \cos \left(\phi_{1}-\psi\right)=0
\end{aligned}
$$

$$
\begin{aligned}
& \int_{0}^{L_{1} / L} \int_{\theta_{i}}^{\theta_{0}} p_{1} \sin \theta d \theta d Z+ \\
& +\int_{0}^{L_{2} / L} \int_{\theta_{i}}^{\theta_{0}} p_{2} \sin \left(\theta-\phi_{1}+\phi_{2}\right) d \theta d Z \\
& \quad-2 p_{\omega} \sin \left(\phi_{1}-\psi\right)=0
\end{aligned}
$$

偏心軸側の軸心軌跡は次の関係式から算出する.

$$
\begin{aligned}
e_{2}= & {\left[e_{1}^{2}+e_{0}^{2}+e_{0}^{\prime}+2\left\{e_{1} e_{0}^{\prime} \sin \left(\phi_{1}-\psi\right)\right.\right.} \\
& \left.\left.-e_{0}^{\prime} e_{0} \cos \left(\psi-\phi_{0}\right)-e_{1} e_{0} \sin \left(\phi_{1}-\phi_{0}\right)\right\}\right]^{1 / 2} \\
\phi_{2} & =\cos ^{-1}\left\{\left(e_{1} \cos \phi_{1}+e_{0} \sin \phi_{0}-e_{0}^{\prime} \sin \psi\right) / e_{2}\right\}
\end{aligned}
$$
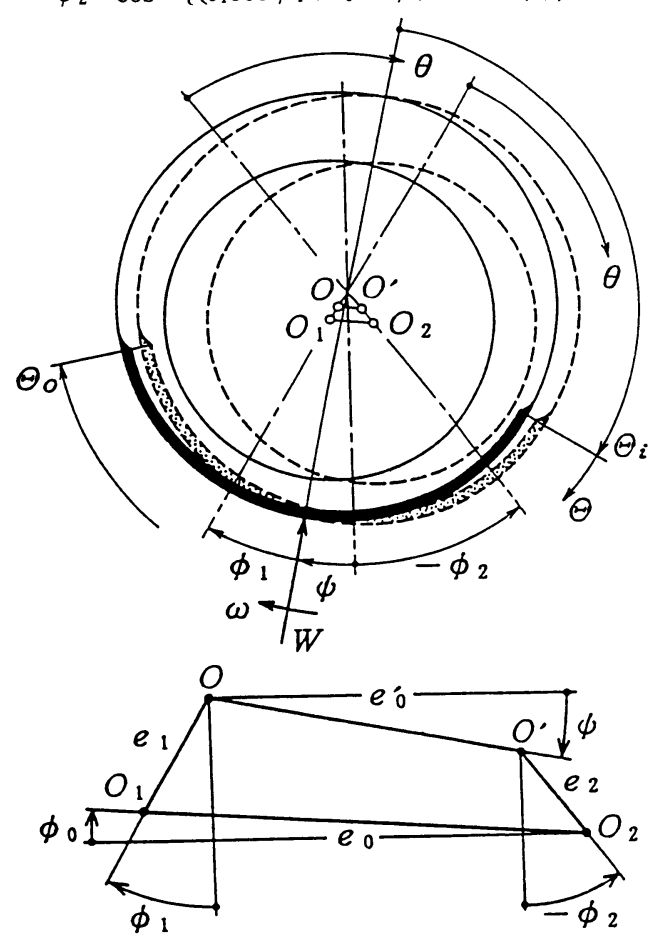

図 4 偏心形軸受の解析モデルと座標采

\section{3. 計算結果}

表 1 に各形式の軸受に対する計算条件を示す．いずれ の形式の軸受の場合る，軸径，軸受の幅および有効円周 角は同一である。従来形とだ円形の軸受に扔ける軸方向 油溝の配列は同じである.その他の寸法はそれぞれの軸 受形式の最適値を用いる. 軸受の面圧および角速度のク ランク角変化を図 5 に示す. 最大面圧はクランク角 $15^{\circ}$ で $12.5 \mathrm{MPa}$ である.

3.1 油膜举動の比較 各形式の軸受に対する 最大油膜圧力 $p_{0}$ と最小油膜厚さ $h_{0}$ のクランク角変化を図 6 に示す．また，最大面圧時の油膜圧力分布を図 7 に示 す.

従来形軸受は，油膜厚さがサイクルを通して極めて薄 
表 1 計算条件

\begin{tabular}{c|l|l|l}
\hline & C T B & E T B & OT B \\
\hline$D$ & \multicolumn{3}{|c}{$640 \mathrm{~mm}$} \\
\hline$L$ & \multicolumn{3}{|c}{$340 \mathrm{~mm}$} \\
\hline$c / r$ & \multicolumn{3}{|c}{$3 \times 10^{-4}$} \\
\hline$\Theta_{0}-\Theta_{i}$ & \multicolumn{3}{|c}{$123.4^{\circ}$} \\
\hline$E_{B}$ & 0.0 & 1.3 & 0.0 \\
\hline$\alpha$ & $42^{\circ}$ & $42^{\circ}$ & - \\
\hline$\delta$ & $39.4^{\circ}$ & $39.4^{\circ}$ & - \\
\hline$m$ & 3 & 3 & - \\
\hline$L_{1} / L_{2}$ & - & - & 3 \\
\hline$e_{0}=e_{0}$ & - & - & $1.5 \mathrm{~mm}$ \\
\hline$\phi_{0}$ & - & - & $-9^{\circ}$ \\
\hline$p_{f}$ & $0 \mathrm{~Pa}$ & $0 \mathrm{PPa}$ & $0.3 \mathrm{PPa}$ \\
\hline$t_{a}$ & \multicolumn{3}{|c}{$1.5 \mathrm{~mm}$} \\
\hline$E$ & \multicolumn{3}{|c}{$60 \mathrm{GPa}$} \\
\hline$\nu$ & \multicolumn{3}{|c}{0.3} \\
\hline$\alpha_{0}$ & \multicolumn{3}{|c}{$0.1 \mathrm{~Pa} \cdot \mathrm{s}$} \\
\hline$\eta_{0}$ & \multicolumn{3}{|c}{$2 \times 10^{-8} \mathrm{~Pa}^{-1}$} \\
\hline$\lambda$ & \multicolumn{3}{|c}{2.18} \\
\hline $2 \phi$ & \multicolumn{3}{|c}{$54.6^{\circ}$} \\
\hline$N$ & \multicolumn{3}{|c}{$84 \mathrm{cpm}$} \\
\hline$C T$
\end{tabular}

C T B : Conventional type bearing

E T B : Elliptical type bearing

OT B : Offset type bearing

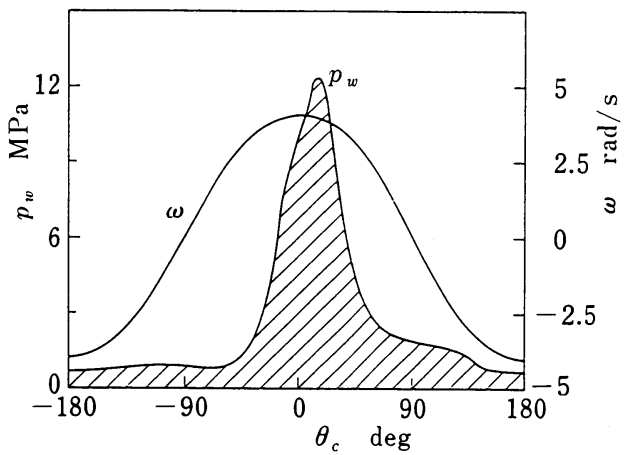

図 5 軸受面圧と軸受角速度のクランク角変化

く面圧の大きい上死点近傍で油膜圧力が著しく増大し， 過酷な潤滑状態である。また油膜圧力分布から中央パッ ドの負荷分担率が非常に大さいことが分かる.

一方，だ円形軸受では，油膜圧力が小さく油膜厚さは 大きくなり，従来形軸受より負荷能力的に優れている.

この種の軸受としては, 油膜圧力が全てのパッドに均一 に発生しかつ小さい，著者らは，だ円形クロス軸受に関 して軸受のだ円率 $E_{B}$ による油膜形状の変化を調べ， $E_{B}$ $>1.1$ では負荷膜内に油膜の縮小拡大部分が二つ形成さ れくさび膜作用が著しく増大すること， $E_{B}$ の最適値は 1.1 から 1.6 の範囲にあることを示した ${ }^{14) 15)}$. だ円軸受で は, くさび膜作用の増大により厚い油膜が形成され油膜
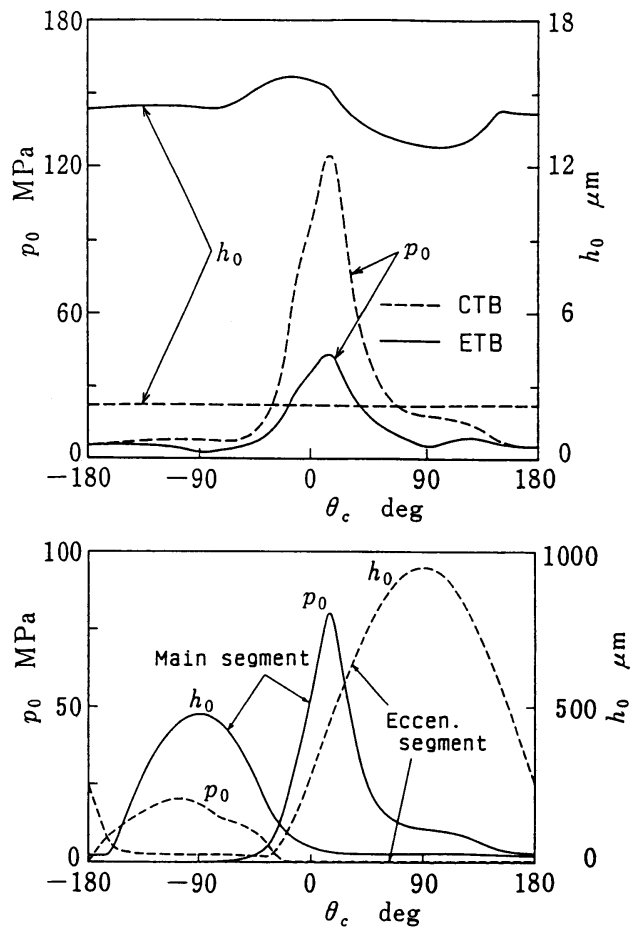

図6 $p_{0}$ および $h_{0}$ のクランク角変化

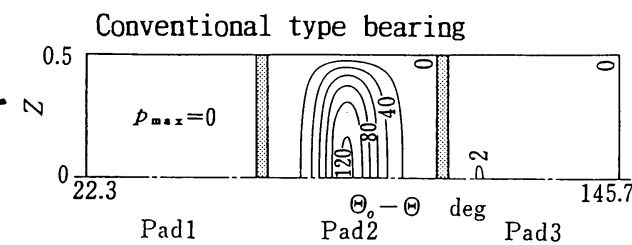

Elliptical type bearing

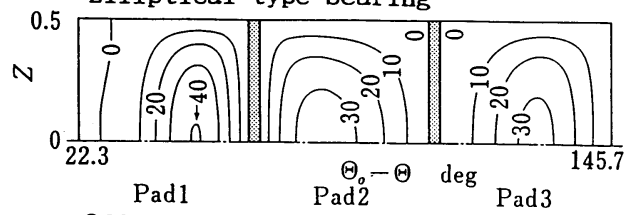

Offset type bearing

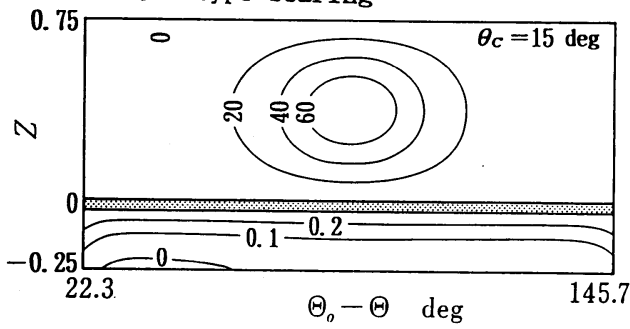

図 7 最大面圧時における油膜圧力分布 （等圧線の単位 $: \mathrm{MPa}$ ) 
圧力はかなり減少する。

偏心形軸受も従来形軸受に比べて非常に優れた負荷能 力を示している。主軸側と偏心軸側の油膜厚さはそれぞ れ異なったクランク角で最小となる。これは，軸と軸受 の相対的な上下動を主軸側と偏心軸側で交互に行うこと による。すななち，主軸側で軸と軸受が接近する運動を している期間で，荷重の大部分を主軸側が負担し，偏心 軸側では軸と軸受面が離され無負荷状態になる。そして 残りの期間では，偏心軸側に軸と軸受の接近運動が移り 荷重は偏心軸側で負担され，主軸側が無負荷状態とな る.このような荷重の負担は前述のだ円軸受と異なり， 主として軸と軸受の接近運動, すなわち油膜のスクイー ズ作用により発生する油膜圧力に基づいている．偏心形 軸受の特長は, 従来形軸受に比べて油膜厚さの変動が大 きいことである。したがって，偏心形軸受では軸が軸受 面から機械的に離されるとき，そのポンピング作用で大 幅に円周給油溝からの油膜交換が促進できる.

以上の解析から，だ円形および偏心形の軸受は従来形 軸受より負荷能力的に優れていることが分かる。一般に クロス軸受では，油膜圧力を軸受メタルの耐圧限界値 60〜80PMa 以下に抑えること, 油膜厚さとその変動量を 大きくすることなどが不可欠である．著者らは既に偏心
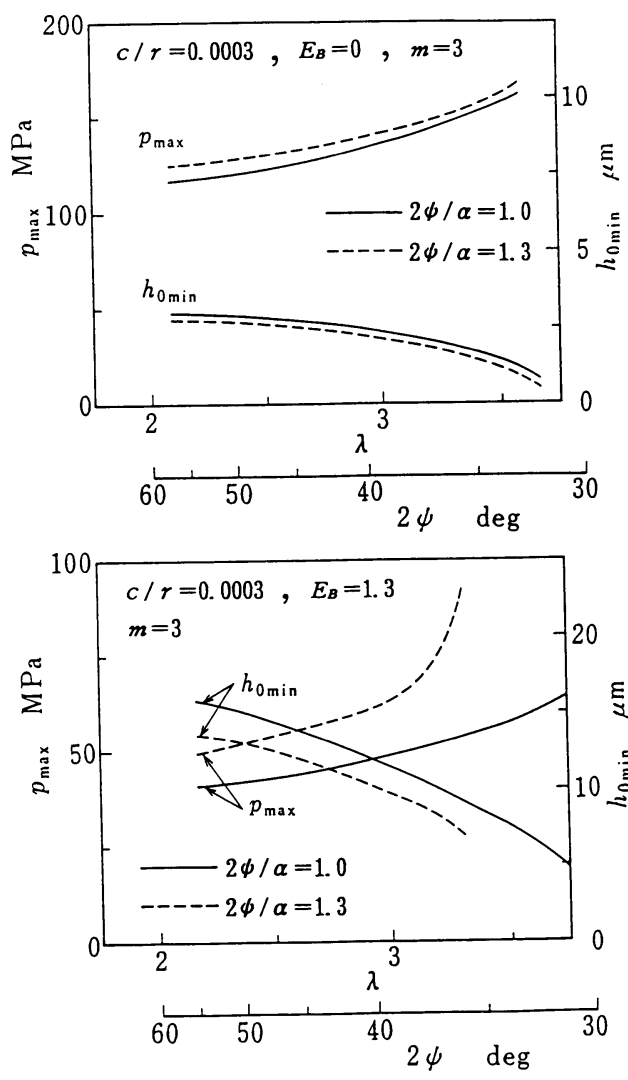

形軸受が優れた負荷能力を有することを実験で示し $た^{4) 9}$ 。一方，だ円形軸受についても実験的検討を進めて いる.

3.2 連捍比の影響 最近の大形ディーゼル機関 は, ストロークボア比が $3 \sim 4$ の長行程機関で連捍比が 2 程度に低減しつつある。軸受の摇動角は連捍比の減少 とともに増大する。クロス軸受の上らに軸受面に軸方向 油溝を配列する場合, 軸受摇動角と油溝の円周方向ピッ 于角の比 $2 \psi / \alpha$, 負荷能力のみならず油膜の交換性 にも密接に関係する. 和栗は $2 \psi / \alpha$ 値の設計基準とし て, 1.3 以上を推奖している ${ }^{4) 9}$.

図 8 にサイクルの最大油膜圧力 $p_{\max }$ 战よび最小油膜厚 さ $h_{0 \min }$ と連捍比 $\lambda$ の関係を示す.計算は, パラメータと して軸方向油溝を有する従来形とだ円形の軸受には $2 \psi$ $/ \alpha$ ，偏心形軸受にはすきま比 $c / r を$ 用いて行った。 た，軸受の有効円周角はそれぞれの設計条件に応じて変 えた.

図より従来形およびだ円形の軸受の場合，入の減少， すなわち $2 \phi$ の増加とともに，いずれの $2 \psi / \alpha$ におい ても $p_{\max }$ は低隇し $h_{0 \min }$ は增大寸る。 そして， $2 \psi / \alpha$ の 小さい，したがって $\alpha$ のさい軸受の方が負荷能力的に 優机てる。ただし，だ円形軸受で $2 \psi / \alpha=1.3$ にお
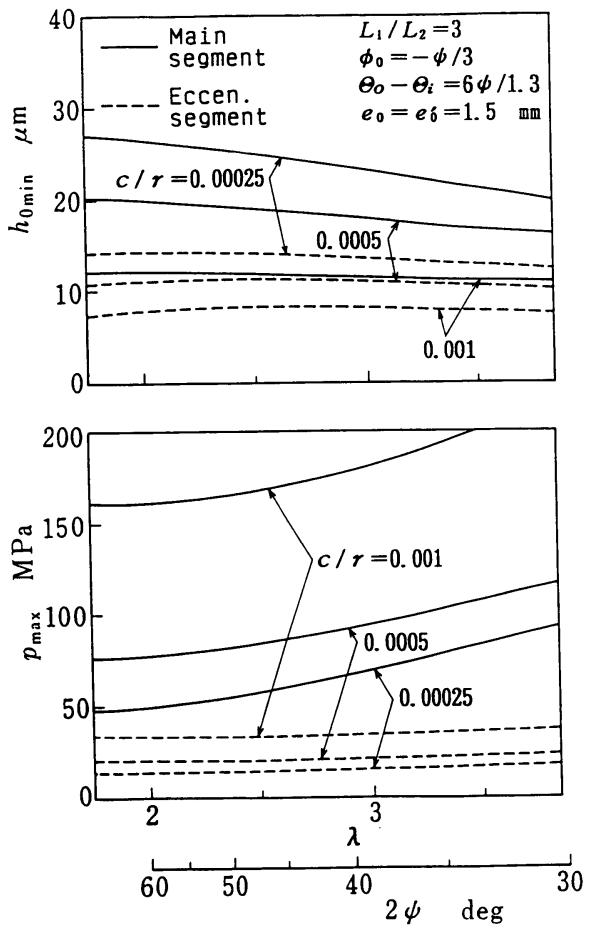

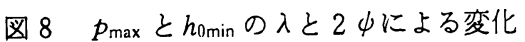


いて $p_{\max }$ が急增している理由は， $\alpha$ の減少につれて最小 油膜厚さ位置が両端パッドの境界近傍に移行し，そこで 高い油膜圧力が発生するためである.

偏心形軸受の主軸側でも，従来形およびだ円形の軸受 と同様に, $\lambda$ の低下とともに $p_{\max }$ は減少し $h_{0 \min }$ は増加す る.この傾向は $c / r$ を変化させても同じであるが， $c /$ $r$ の 0.001 と 0.00025 の比較から分かるように, $p_{\max }$ の減 少と $h_{0 \min }$ の増大に及ぼす $c / r$ の効果は著しい.一方, 偏 心軸側の $p_{\max }$ および $h_{0 \text { min }}$ の変化は小さい.

以上の各形式の軸受に対する計算結果から次のような ことが言える，入の減少による軸受摇動角の増大は負荷 能力の面から望ましい，そして従来形およびだ円形の軸 受のように軸方向油溝を有する軸受では, 油膜の交換能 力を損なわない範囲で軸方向油溝のピッチ角をできるだ け大きく設計すべきである。

次章で従来形軸受の負荷能力に及ぼす $2 \phi や \alpha$ 効果 について実験的な検討結果を述べる.

\section{4. 実 験}

\section{1 実験方法図9に実験で用いたクロス軸受} の閏滑性能試験機を示す。これは，試験軸(1)がその両端 をコロ軸受(2)で支持されながら，クランク機構(3)により 摇動角 $20 \sim 55^{\circ}$ の範囲で摇動運動を行ら軸駆動方式の試 験機である。軸受に掛かる荷重は，図中に示すようなサ イクル的変化をする変動荷重である．軸受はいずれも幅
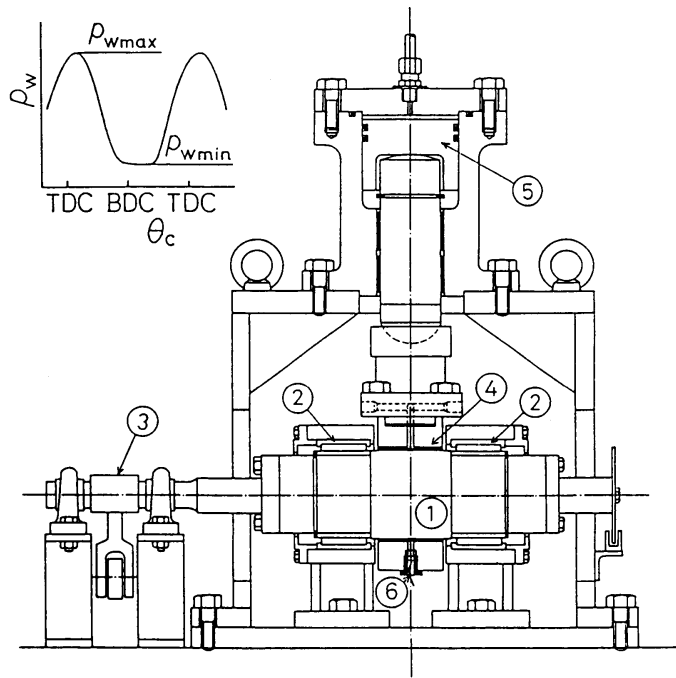

1 Test journal

2 Roller bearing

3 0scillation device 4 Test bearing

5 0il pressure ram

\section{Vibration tranducer}

図 9 実験装置概略図
$66 \mathrm{~mm}$, メタル合金のライニング肉厚 $1.25 \mathrm{~mm}$ であり, 表 面は錫-鉛合金でオーバレイされている．供試軸は材質 が S52Cの軟鋼であり, 直径が $100 \mathrm{~mm} に$ 超仕上げされた すべり面を有する．軸受メタルの材質は，ホワイトメタ ルと錫ーアルミニウム合金である.軸受すきま比は 0.000 3 とした.

実験は，軸受メタルの焼付けに対する負荷限界を求め る試験方で行い，搯動速度と潤滑油温度をそれぞれ $300 \mathrm{cpm}$ と $50^{\circ} \mathrm{C}$ の一定にし, 変動軸受面圧のサイクル最 小值 $p_{\omega \min }$ とサイクル最大值 $p_{\omega \max }$ をとをにステップ状に 増加させた．メタルが焼付きを起こす負荷の限界は，熟 電対でメタル温度を測定しその急上昇より判定した。供 試潤滑油にはエンジン油SAE20(無添加)を用い, 給油量 は $180 \mathrm{~g} / \mathrm{min}$ の一定とした。

4.2 実験 結果表 2 に負荷限界試験の結果, 図10に試験後の軸受メタルの写真をそれぞれ示す. 焼付 き限界の面圧 $p_{\omega \min }$ と $p_{\omega \max }$ は, 油溝あるいはパッドの 数, 油溝のピッチ角, 搯動角や軸受メタルの組合せの違 いにより複雑に変化している. $p_{\omega \max }$ の値に注目すると， その値は $2 \psi / \alpha$ と密接に関連している. ホワイトメタ ルについて $2 \phi / \alpha, \alpha$ および $n$ の $p_{\omega \max }$ に及ぼす影響 を図11に示す. 前章では，2 $4 / \alpha$ を小さく $\alpha$ を大きく することが望ましいと述べたが，実験では若干異なる結 果が得られた。すなわち， $p_{\omega \max }$ はいずれの $\alpha$ について も $2 \psi / \alpha$ の増加に伴い増大する. $p_{\omega \max }$ 之 $\alpha$ の関係は $2 \phi / \alpha$ の大きさにより異なり, $p_{\omega \max }$ 值は, $2 \psi / \alpha$ の 1 近傍では $\alpha$ の減少, $2 \psi / \alpha$ の 1.3 近傍では $\alpha$ の増 大とともにそれぞれ大きくなる．油膜の交換能力への 2 $\psi / \alpha$ 值の影響とすべり面の冷却能力への $\alpha$ 値の影響と が重なる形で現れている.

軸受メタルの材質を比較すると，図12に示すよらに錫 ーアルミニウム合金の $p_{\omega \max }$ がホワイトメタルのそれよ りも大きく，耐焼付き性としては錫-アルミニウム合金 の方が優れている.負荷能力と油膜交換能力の向上に

表 2 負荷限界試験結果

Bearing metal: Thite metal

\begin{tabular}{|c|c|c|c|c|c|c|c|}
\hline No. & $n$ & $\begin{array}{c}\alpha \\
{[\mathrm{deg}]}\end{array}$ & $\bar{\lambda}$ & $\begin{array}{c}2 \psi \\
{[\mathrm{deg}]}\end{array}$ & $2 \phi / \alpha$ & $\begin{array}{r}p_{w \operatorname{in}} \\
{[\mathrm{MPa}]}\end{array}$ & $\begin{array}{l}p_{\text {wax }} \\
{[\mathrm{YPa}]}\end{array}$ \\
\hline 1 & 4 & 30 & 3.86 & 30 & 1.0 & 1.8 & 26.4 \\
\hline 2 & 4 & 40 & 2.92 & 40 & 1.0 & 2.1 & 25.6 \\
\hline 3 & 4 & 30 & 2.92 & 40 & 1.33 & 6.2 & 52.7 \\
\hline 4 & 4 & 40 & 2.16 & 55 & 1. 38 & 12.3 & 67.6 \\
\hline 5 & 4 & 40 & 2.16 & 55 & 1.38 & 9.9 & 64.5 \\
\hline 6 & 6 & 20 & 5.76 & 20 & 1.0 & 5.1 & 36.1 \\
\hline 7 & 6 & 20 & 3.86 & 30 & 1.5 & 4.3 & 41.9 \\
\hline 8 & 6 & 20 & 2.92 & 40 & 2.0 & 4.3 & 43.9 \\
\hline \multicolumn{8}{|c|}{ Bearing netal: Tin-Aluninum } \\
\hline & $n$ & $\begin{array}{c}a \\
{[\mathrm{deg}]}\end{array}$ & $\bar{\lambda}$ & $\begin{array}{c}2 \psi \\
{[\mathrm{deg}]}\end{array}$ & $2 \phi / \alpha$ & $\begin{array}{r}P_{\text {wm I n }} \\
{[\mathrm{IPa}]}\end{array}$ & $\begin{array}{r}p_{\text {wmax }} \\
{[\mathrm{YPa}]}\end{array}$ \\
\hline 9 & 4 & 30 & 3.86 & 30 & 1.0 & 4.3 & 42.4 \\
\hline 10 & 4 & 30 & 2.92 & 40 & 1.33 & 6.4 & 66.0 \\
\hline 11 & 6 & 20 & 3.86 & 30 & 1.5 & 8.6 & 46.4 \\
\hline 12 & 6 & 20 & 2.92 & 40 & 2.0 & 7.0 & 49.1 \\
\hline
\end{tabular}




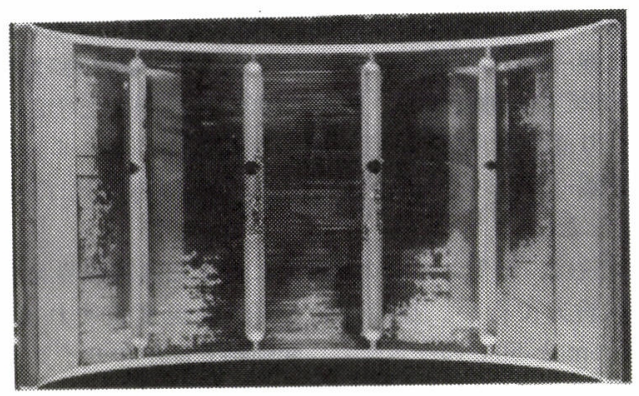

White metal(Test No.3)

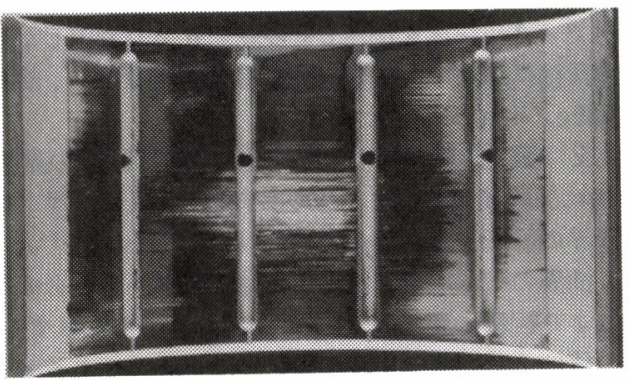

Tin-Aluminum(Test No.10)

図10 負荷限界試験後の軸受メタル写真

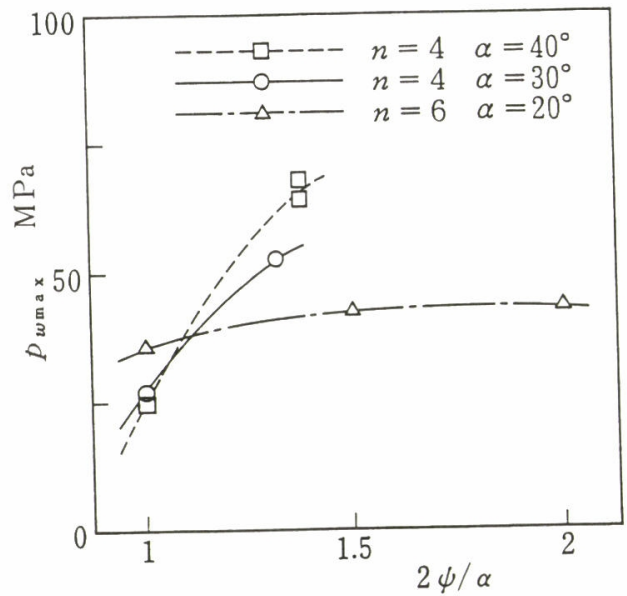

図11 $p_{w \max }$ と $2 \varphi / \alpha, \alpha お$ よびnの関係

(軸受材質：ホワイトメタル)

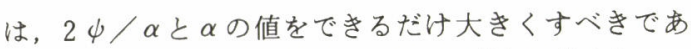
る。すなわち，入の減少による $2 \psi$ の増大は望をしい。 ホワイトメタルは, 錫一アルミニウム合金よりも耐焼付 き性に劣るが， $\alpha$ を増大させることにより負荷限界もか なり改善できる。したがって，2 $2 \psi / \alpha>1.3$ 执いて パッド数を少なくするために, 油溝のピッチ角をできる だけ大きくすべきである。

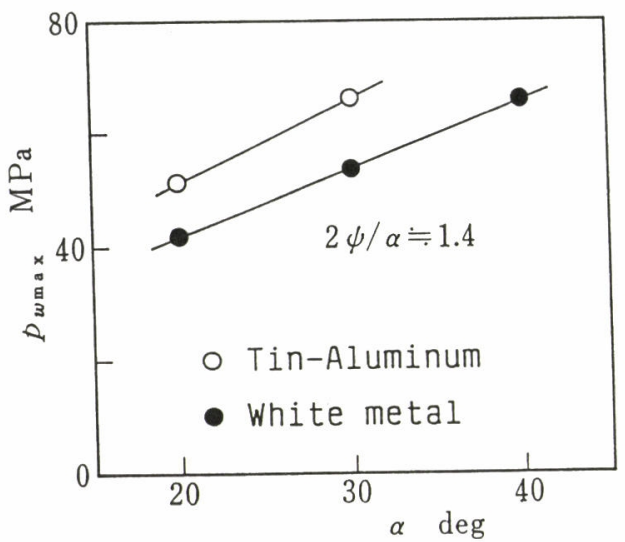

図12 p umax とaおよび軸受材質の関係

\section{5. 結 論}

本研究の結果を要約すると次のようになる.

(1) 三つの異なる形式のクロス軸受の潤滑特性の比較か ら、だ円形抒よび偏心形の軸受は従来形軸受に比べ負荷 能力的に優れている。偏心形軸受は, 負荷面が主軸側と 偏心軸側で交互に代わりすべり面の油膜が積極的に交換 されるため, 油膜の交換能力に優れた軸受構造である. また, 従来形軸受で不可欠であった軸方向油溝を廃止で きるといら利点も有する。

（2）負荷能力の向上の面から，連捍比を減少させ軸受の 摇動角を増大させることは、いずれの形式の軸受に招い ても有利である。特に，軸方向油溝を有する従来形とだ 円形の軸受では，油溝のピッチ角を大きくすることがで き負荷能力が向上する。

（3）従来形軸受の負荷限界試験から, 油膜の交換能力は 摇動角と油溝のピッチ角の比に著しく影響を受ける。こ の比を 1.3 以下に設計すべきではない.

軸受材質としては, ホワイトメタルより錫ーアルミニウ 么合金が耐焼付き性に優れている。

本研究の遂行に当たり，種々ご援助頂いた大同メタル 工業株式会社・田中正，吉田一誠の両氏に謝意を表しま す。また，資料整理にご協力頂いた大分大学文部技官・ 嶋田不美生氏にも感謝致します。

記号
c : : 半径すきま
$D$ : 軸径
e : 偏心量
$e_{0}, e_{0}^{\prime} \quad$ : 偏心形軸受の軸, 軸受の各偏心距離
E : 弾性変形
$E_{B} \quad:$ 軸受のだ円率
$h$ : 油膜厚さ
$h_{0}$ : 最小油膜厚さ
$H$ : 無次元油膜厚さ $=h / c$ 
$k \quad:$ 軸受メタルの変形係数 $=t_{a}\left\{1-2 \nu^{2} /(1-\nu)\right\} / E$

$L \quad$ : 軸受幅

$m \quad$ : パッド数

$n$ : 軸方向油溝の数

$N$ : 軸受の摇動数

$p$ : 油膜圧力

$p_{0}$ : 最大油膜圧力

$p_{f}:$ : 給油圧力

$p_{\omega} \quad$ : 軸受面圧 $=W / D L$

$P \quad:$ 修正圧力関数 $=\Psi H^{2 / 3}$

$q:$ 換算圧力 $=\left\{1-\exp \left(-\alpha_{0} p\right)\right\} / \alpha_{0}$

$r$ : 軸半径

$r_{a} \quad:$ だ円の副小円半径

$r_{B}:$ だ円の円弧半径

$t \quad:$ 時間

$t_{a} \quad$ : 軸受メタルの厚さ

$W \quad$ : 軸受荷重

$z \quad$ : 軸方向座標

$Z \quad:$ 無次元軸方向座標 $=z / L$

$\alpha$ : 軸方向油溝の円周方向ピッチ角

$\alpha_{0}:$ 粘度の圧力係数

$\delta \quad:$ パッドの有効円周角

$\delta_{B}$ : だ円の長軸と短軸の半径差

$\varepsilon:$ 偏心率 $=e / c$

$\eta \quad:$ 粘度

$\eta_{0}:$ 常圧粘度

$\theta:$ 円周角 $=\Theta-\phi$

$\theta_{i 1}: i$ 番目のパッド先端までの円周角

$\theta_{i 2}: i$ 番目のパッド後端までの円周角

$\theta_{i}$ : 円周方向流入角 $=\Theta_{i}+\psi-\phi$

$\theta_{0}:$ 円周方向流出角 $=\Theta_{0}+\psi-\phi$

$\theta_{c}$ : :クランク角

$\Theta \quad$ : 荷重方向から測る円周角

$\Theta_{0}-\Theta_{i}:$ 軸受の有効円周角

$\lambda:$ 連捍比

$\nu:$ :゚アアンン比

$\tau=\omega_{0} t$

$\phi$ : 偏心角

$\phi_{0}:$ 軸心線の水平からの傾き角

$\psi$ : 軸受の摇動角

$\Psi:$ : 無次元換算圧力 $=(c / r)^{2} q / \eta_{0} \omega_{0}$

$\omega$ : 軸受の角速度

$\omega_{0}:$ :クランク軸角速度

$\bar{\omega}=\omega / \omega_{0}$

\section{文献}

1）和栗・ほか 2 名，機論，48-425，C (昭57-1)，86.

2) Wakuri, Y., ほか 2 名, Proc.JSLE Int. Tribol. Conf., II (1985), 325.
3）和栗・ほか 2 名, 舶機誌, 22-3(昭62-3)，207.

4) Wakuri, Y., ほか 2 名, 17th CIMAC Paper D-41(1987).

5) Ciliberto, G. and Mariani, L., 12th CIMAC A21 (1977).

6) 和栗・ほか 2 名, 機論，47-424，C (昭56-12)，1643.

7) 和栗・ほか 2 名, 舶機誌, 17-5 (昭57-5)，380.

8）和栗・はか 2 名，機論，51-461，C (昭60-1)，114.

9) Wakuri, Y., and Soejima, M., Proc. JSLE Int. Tribol. Conf., II (1985), 319.

10) Booker,J.F., ほか 2 名, Trans. ASME, J.Lubr. Technol., 104-4(1982-10), 478 .

11) Booker,J.F., ほか 2 名, Trans. ASME, J.Lubr. Technol., 106-3(1984-7), 352.

12) Goenka, P.K., and Booker,J.F., Trans. ASME, J.Lubr. Technol., 105-1 (1983-1), 1 .

13) Martin, F., Tribology of Reciprocating Engines, (1983), 9 , Butterworths.

14）和栗・ほか 2 名, 機論, 55-510, C (平 1-2)， 431 .

15）和栗・ほか 2 名, トライボロジスト，34-8，(平1-8）, 52 .

\section{[質 疑 応 答]}

質問者 川崎重工業(侏)明石技術研究所エンジン研究室 徳永佳郎

[質問]以下のことについて質問する.

（1）だ円形および偏心形の軸受は，従来形軸受に比べて 負荷能力的に優れていることを示しているが，これらの 軸受は実用されているか.

（2）だ円形と偏心形の軸受を油膜厚さと負荷能力につい て比較すると, どちらの軸受が優れているか。

（3）だ円形軸受が従来形軸受よりも優れていることは理 解できたが，だ円形軸受はどのようにして製造するかを 示して欲しい.

（4）図 11 において, $p_{\omega \max }$ は $2 \psi / \alpha$ が 1 近傍では $\alpha$ の 減少とともに，24/ $\alpha$ が 1.3 近傍では逆に $\alpha$ の増大と ともに増加しているが, その理由は何か.

(5) クロス軸受にライニングするメタル合金材として， ホワイトメタルやアルミ゙ウム合金が通常用いられる が，本文中に示された三つの形式の軸受にはどのよらな 軸受材質が適しているか.

[回答]

（1）偏心形軸受の実用化について，イタリアの Grandi Motori Trieste の Drei は1), シリンダ直径が $600 \mathrm{~mm}$ か ら 1060mmの大形ニサイクルディーゼル機関のクロス軸 受に既に多数使用したことを報告している。しかし，だ 円形軸受については未だ実用化されてない。

（2）軸受の代表的な油膜特性値である $h_{0 \text { min }}$ や $p_{\max }$ に最も

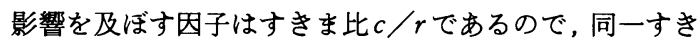
ま比のもとで両者の比較を行う。また偏心形軸受は, 主 軸側の負荷条件が偏心軸側より厳しいので, 主軸側の油 膜特性值を用いる。まず図 8 の $c / r=0.0003$ において， 
偏心形軸受の $h_{0}$ min の方がだ円形軸受のそれよりもかな り大きい，そして図6に示すように，偏心形軸受の方は 油膜厚さが大きく变動する。つまり, 油膜厚さに関して は偏心形軸受の方が優れている.一方, 両形式の軸受と も $p_{\max }$ はほぼ同じであり，負荷能力的にはほとんど差が ない，したがって，軸受性能としては偏心形軸受の方が 優れていると思われるが，この問題は今後実験的に検討 したい。

(3) 著者らはだ円形軸受の最適軸受形状を検討し， $E_{B}$ の 最適値は 1.1〜1.6であることを示した ${ }^{3)}$. それは本研究 の計算条件に打いて，短軸方向の半径すき $96 \mu \mathrm{m}$ に対 して長軸方向の半径すきが $200 \mu \mathrm{m} \sim 250 \mu \mathrm{m}$ の範囲 の大きさに相当する。したがって，軸受面の形状をだ円 に加工するのは必ずしも容易でない，だ円形軸受の加工 法として次の二つが考光られる，一つは，軸受の中心軸 を切削工具の回転軸から僅かに傾けて軸受面をボーリン グする方法である。るら一つは，厚さが円周方向で不均 一なシェル形の軸受メタルを製作し使用する方法であ る.

（4）従来形軸受に扮いて，油膜の粘性摩擦により軸と軸 受の間で発生する熱は，軸受の摇動すべりによる軸方向 油溝との油膜交換で除去しなければならない，そのとき の発生熱量はすべり速度やパッドの面積すなわち $\alpha$ の大 きさなどに関係し，油膜交換の能力は $2 \psi / \alpha$ の大きさ
と密接に関係する. 図 11 の実験值 $p_{\omega \max }$ は, $2 \psi / \alpha$ の 影響を受けると同時に $\alpha$ の影響も受けて変化している. $2 \psi / \alpha$ 値が 1.3 近傍（この値を越えると油膜交換が十 分に行われる）では， $\alpha$ の増大に伴い負荷能力 $p_{\omega \max }$ は 増大する，ところが， $2 \psi / \alpha$ 值が 1 近傍（油膜交換が

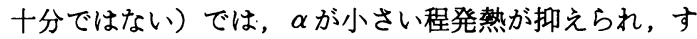
べり面の冷却が有利になり， $p_{\omega \max }$ が増大するためであ ろうと考える。

（5）一般に軸受合金材は，軸受の荷重，すべり速度，軸 と軸受間の取付け方法などにより異なる。軸受に通常使 用されている材質は，なじみ性の高いホワイトメタルか 耐疲労性の大きいアルミニウム合金であり，前者は低荷 重軸受に，後者は高荷重軸受に適している。このことか ら，次のような軸受の合金材と形式の組合わせが考えら れる.

従来形軸受では，負荷能力の大きい接触軸受状態を実 現するために軸受すきまをできるだけ小さくしている。 したがって，従来形軸受にはなじみ性のよいホワイトメ タルが適している。一方, 偏心形軸受は油膜厚さの変動 や油膜圧力が比較的大きいので，なじみ特性よりもむし ろ耐疲労性の大きいアルミニウム合金が適している。だ 円形軸受には，比較的厚い油膜厚さが形成され油膜圧力 もそれ程大きくないので，両材質とも適合し得る。 